\title{
Genotype Is Primarily Responsible for Variance in Table Beet Geosmin Concentration, but Complex Genotype $\times$ Environment Interactions Influence Variance in Total Dissolved Solids
}

\author{
Solveig J. Hanson and Irwin L. Goldman \\ Department of Horticulture, University of Wisconsin-Madison, 1575 Linden Drive, Madison, WI \\ 53706
}

\begin{abstract}
AdDitional INDEX words. aromatic volatiles, Beta vulgaris, earthiness, flavor, flavor chemistry, red beet, soluble solids
ABSTRACT. Earthy aroma and sweet flavor, conferred by the volatile terpenoid geosmin (trans-1,10-dimethyl-trans-9decalol) and sucrose, respectively, are two essential flavor components of table beet (Beta vulgaris ssp. vulgaris). To elucidate the influence of genotype, growing environment, and fertilizer treatment on geosmin concentration and sucrose [as total dissolved solids (TDS)] in table beet, a field-based genotype $\times$ environment study was conducted using a split-split plot design. Four site $\times$ year combinations served as whole plots; $\mathrm{MgSO}_{4} \cdot \mathrm{H}_{2} \mathrm{O}$ and $\mathrm{CaSO}_{4}$ comprised split plot fertilizer treatments; open-pollinated cultivars Bull's Blood and Touchstone Gold, F1 hybrid Merlin, and inbred line W357B constituted split-split plot genotype treatments. Geosmin concentration was measured via gas chromatography-mass spectrometry using headspace solid-phase microextraction, and TDS was measured via refractometry. Variation in geosmin concentration was attributable to a strong genotype effect and significant genotype $\times$ year and year $\times$ site interactions. Genotypes were observed to have characteristic geosmin concentration and variance, despite being grown in soils with widely divergent physical and chemical properties. While a significant genotype main effect was also present for TDS, it occurred in the context of significant four-way and three-way genotype $\times$ environment interactions, plus significant effects of year and year $\times$ site interaction. Neither geosmin concentration nor TDS was significantly influenced by fertilizer treatment or fertilizer $\times$ environment interactions, averaged across genotypes. Genetics determined a larger proportion of variance for geosmin concentration than TDS in the four table beet genotypes assessed, as reflected in repeatability measurements of 0.90 and 0.43 , respectively. This experiment provides support for the primacy of genotype in determining table beet geosmin concentration and a comparatively moderate role of genotype in determining table beet TDS. Thus, genetic manipulation of table beet geosmin could yield cultivars with signature flavor characteristics to serve both niche and mainstream consumer groups, expanding market opportunities for breeders and growers.
\end{abstract}

Table beet is a minor vegetable crop with strong economic importance in Wisconsin, which led 2017 U.S. table beet production with over 1600 ha harvested. The United States table beet harvest serves both processing $(52 \%)$ and fresh (48\%) markets (U.S. Department of Agriculture, 2017) with both standard red table beets and lesser volumes of novel cultivars (Goldman and Navazio, 2003). Flavor is critical to consumer acceptance of horticultural crops, so while different table beet flavor profiles may be appropriate for different markets (Dawson and Healy, 2018) and preparation methods (Bach et al., 2015), achieving consumer-accepted flavor is essential to table beet marketability. Four chemical compounds are documented to be associated with table beet flavor: geosmin, sucrose, oxalate, and saponins. Earthy aroma, conferred by the volatile terpenoid geosmin (Gerber, 1967), is identified as the signature flavor of table beet (Goldman and Navazio, 2003) but can be unpalatable in excess (Tyler et al., 1979). Sucrose, the major saccharide molecule in table beet root (Bach et al., 2015), contributes sweet flavor and is commonly measured as TDS. Oxalate is present in table beet (Freidig and Goldman, 2011) and has been associated with abrasive

Received for publication 5 June 2019. Accepted for publication 6 Sept. 2019. We wish to thank Nicholas Keuler and Julie Dawson for assistance with statistical analysis.

I.L.G. is the corresponding author. Email: ilgoldma@wisc.edu. sensory properties in other plants (Korth et al., 2006; Salinas et al., 2001). Saponins, which confer bitter flavor in other crops, have also been identified in table beet (Mikołajczyk-Bator et al., 2016). The present research seeks to understand the genetic control and genotype $\times$ environment interactions associated with geosmin concentration and TDS in table beet, to facilitate breeding for desired table beet flavor.

The earthy flavor in table beet is conferred by geosmin (trans-1,10-dimethyl-trans-9-decalol), the volatile organic compound that imbues moist earth with its distinctive aroma (Marshall and Hochstetler, 1968). Geosmin is synthesized by a diverse group of bacteria, cyanobacteria, and fungi; Streptomyces bacteria are recognized as prominent producers of geosmin (Spiteller et al., 2002). Geosmin is known to occur in several Amaranthaceae family members, including spinach (Spinacea oleracea), swiss chard (B. vulgaris ssp. cicla), and table beet (Acree and Lee, 1976), while dehydrogeosmin, a compound that can assume a conformation identical to geosmin, has been identified in six genera of the Cactaceae family (Schlumpberger et al., 2004). Humans are exceedingly sensitive to geosmin and able to detect the molecule at concentrations as low as 10 to $20 \mathrm{ng} \cdot \mathrm{L}^{-1}$ water (Tyler et al., 1979). Geosmin is present in drinking water, wine, beer, and various foods, often rendering the affected water or foodstuff unpalatable (Buttery et al., 1976; Darriet et al., 2000; Frisvad et al., 1997). In a sensory study using table beet juice, geosmin 
conferred characteristic earthy flavor up to a $5.8 \mu \mathrm{g} \cdot \mathrm{L}^{-1}$ threshold; geosmin concentration above this level was identified by consumers as "too earthy to be beet-like," while very low geosmin concentration $\left(0.36 \mu \mathrm{g} \cdot \mathrm{L}^{-1}\right)$ was perceived as lacking characteristic table beet flavor (Tyler et al., 1979). In addition, earthy flavor is anecdotally cited as a reason that consumers avoid table beets (Lu et al., 2003b). Thus, geosmin may be perceived as either pleasing or undesirable, depending on its concentration and the context in which it occurs.

The microbial biosynthesis of geosmin begins with precursor molecule farnesyl diphosphate (FPP). In the presence of a single, bifunctional geosmin synthase enzyme and $\mathrm{Mg}^{2+}$ cofactors, FPP is cyclized into an 85:15 mixture of germacradienol and germacrene D. Next, a cyclization-fragmentation reaction converts the germacradienol fraction into geosmin. The presence of divalent cations $\mathrm{Cu}^{2+}$ and $\mathrm{Fe}^{2+}$ decreases geosmin synthesis in vitro (Jiang et al., 2006) and in Streptomyces halstedii (Schrader and Blevins, 2001), perhaps due to competition with $\mathrm{Mg}^{2+}$ for access to geosmin precursor compounds. A geosmin synthase gene has been found in Streptomyces coelicolor (Cane and Watt, 2003) and several other microbial species (Giglio et al., 2008; Singh et al., 2009).

In 2003, Lu et al. developed a headspace solid-phase microextraction (HSPME) protocol for gas chromatography-mass spectrometry (GC-MS) to quantify geosmin concentration within a table beet slurry matrix. This methodology facilitated inquiry into three possible hypotheses regarding the presence of geosmin in table beet. First, table beet plants might associate preferentially with geosmin-producing microbes, perhaps via genotype-specific root exudates. Geosmin is known to accumulate in and directly under the root epidermis in table beet (Lu et al., 2003a; Tyler et al., 1978), lending initial support to this hypothesis. However, the presence of geosmin in table beet tissue grown in autoclaved soil (Freidig and Goldman, 2014) and sterile tissue culture (Maher and Goldman, 2018) refutes it. Second, geosmin could be produced within table beet tissue by endophytic microbes. However, genomic probes of table beet tissue grown in sterile culture revealed no obvious prokaryotic sequences other than those present in chloroplast DNA (Maher and Goldman, 2018). Thus, evidence accrues for a third possibility: that of endogenous production of geosmin by table beet plants. In support of this possibility - but not expressly in contradiction to the others - table beet populations were responsive to recurrent selection for high and low geosmin concentration, with realized heritabilities of 0.23 and 0.7 for high and low geosmin populations, respectively (Maher and Goldman, 2017).

To search for a geosmin synthase gene in B. vulgaris, Maher (2017) queried the sugar beet (B. vulgaris ssp. vulgaris) reference genome using Position-Specific Iterative Basic Local Alignment Search Tool (PSI-BLAST) for proteins with similar three-dimensional structure as the $S$. coelicolor geosmin synthase gene, yielding one predicted linalool-synthase-like protein and two hypothetical proteins. The latter two proteins - a terpene synthase and an isoprenoid synthase-are located adjacent to one another on chromosome 8, and both appear to have two functional domains, as does geosmin synthase (Maher, 2017). While these proteins have not been proven to synthesize geosmin from precursor molecules, their existence suggests a mechanism by which geosmin could be produced endogenously via the $B$. vulgaris genome.

Sweet flavor is another key sensory attribute of table beet, and sugars occur in table beet mainly as sucrose, although small amounts of fructose and glucose are also present (Bach et al., 2015). Sucrose concentration in sugar beet, which shares both species and subspecies with table beet, is highly heritable, quantitatively controlled, and directly related to total root dry mass. Sucrose content in sugar beet has been increased successfully by selecting for root specific gravity - proportionally higher dry matter and lower water content - and for a higher root:shoot biomass ratio (McGrath and Panella, 2018). Narrow-sense heritability $\left(h^{2}\right)$ for percent sugar content was estimated at 0.60 in a testcross population of 924 sugar beet genotypes (Würschum et al., 2011). Five quantitative trait loci (QTL) have been associated with sucrose content in sugar beet (Schneider et al., 2002), and several seemed to colocalize with QTL for water content in a preliminary study (Trebbi and McGrath, 2007). Bidirectional selection for TDS in high pigment table beet populations, using an index integrating TDS and betalain pigment concentration, showed moderate response to upward selection and limited response to downward selection, perhaps because of the essential role of sucrose metabolites in the betalain synthesis pathway (Goldman et al., 1996; Wolyn and Gabelman, 1990). Thus, while sucrose concentration in B. vulgaris is under substantial genetic control, environmental factors also contribute to this phenotype.

Lay garden literature suggests that table beet flavor is superior in soils with high magnesium content (High Mowing Organic Seeds, 2016). While soil $\mathrm{Mg}^{2+}$ deficiency is known to inhibit root sugar accumulation in sugar beet (Hermans et al., 2004), perhaps due to the central role of magnesium ions in sucrose-producing chlorophyll molecules (Shaul, 2002), it is plausible that $\mathrm{Mg}^{2+}$ deficiency also limits geosmin synthesis. That is, $\mathrm{Mg}^{2+}$ is an essential cofactor in microbial geosmin biosynthesis, and if a hypothetical $B$. vulgaris geosmin synthase enzyme also required $\mathrm{Mg}^{2+}$, soil magnesium concentration also could affect geosmin concentration in table beet. In soil, $\mathrm{Mg}^{2+}$ competes with other cations for space on the negatively charged cation exchange complex; after entering plant roots through both apoplasmic and symplasmic pathways, it is loaded into xylem cells and unloaded at ubiquitous locations in plant shoots. Within each plant shoot cell, a quantity of $\mathrm{Mg}^{2+}$ is complexed with adenosine triphosphate (ATP), but the vacuole functions to sequester free $\mathrm{Mg}^{2+}$, tightly regulating its concentration within the cytosol (Shaul, 2002). In sugar beet plants, supplemental magnesium fertilization has been shown to significantly increase in planta $\mathrm{Mg}^{2+}$ concentration (Durrant and Draycott, 1971; Zengin et al., 2009), root yield (Grzebisz, 2013; Zengin et al., 2009), and nitrogen uptake efficiency (Grzebisz, 2013). Effects on yield were most significant when magnesium fertilizer was added to $\mathrm{Mg}^{2+}$-deficient soils with low cation exchange capacity (CEC) (Grzebisz, 2013; Zengin et al., 2009). Magnesium fertilization of sugar beet caused decreased in planta calcium concentration (Durrant and Draycott, 1971), showing that $\mathrm{Mg}^{2+}$ and $\mathrm{Ca}^{2+}$ act as competing cations within sugar beet tissue. The effect of magnesium fertilization on geosmin concentration in Beta species has not been studied.

Flavor compounds in horticultural crops are known to vary with genotype, environment, and their interaction, but this variation seems to be specific to crop, compound, and environment (CebollaCornejo et al., 2011; Crespo et al., 2010; Duckham et al., 2001, 2002; Jensen et al., 1999). Previous genotype $\times$ environment studies of TDS in table beet showed strong environmental effects and limited realized heritability (Goldman et al., 1996), but these estimates were attained using genotypes selected for high pigment concentration rather than commercial horticultural use. In a study of geosmin concentration in table beet, Freidig and Goldman (2014) found highly significant genotype and non-crossover genotype $\times$ environment interaction effects, plus a moderately 
significant environmental effect. The genotype $\times$ environment interaction reflected significantly different geosmin concentration between field and greenhouse environments within cultivar, perhaps due to the smaller size of the greenhouse-grown roots. Indeed, an early study analyzing whole-root samples of 'Ruby Queen' table beet found significantly higher geosmin concentration in smaller roots than in larger roots (Tyler et al., 1978), likely due to incorporation of proportionally more epidermal tissue to core root tissue in homogenate made from small roots. Freidig and Goldman (2014) used a sampling method designed to standardize the proportion of epidermal to core root tissue in each sample, but because root size cannot be parsed from growing environment in that study, it remains possible that differential root size contributed to the observed genotype $\times$ environmental interaction for geosmin concentration. To disentangle the effect of root size from that of growing environment on geosmin concentration and, more broadly, to investigate the influence of genotype, growing environment, and fertilizer treatment on geosmin concentration and TDS in table beet, a genotype $\times$ environment study is warranted that standardizes root size, compares multiple field environments, and uses mainstream commercial cultivars.

\section{Materials and Methods}

SPLIT-SPLIT PLOT FIELD EXPERIMENT. Four table beet genotypes were planted with a continuous drill seeder (Planet Junior; Cole Planter Co., Albany, GA) modified with a cone attachment at two sites in each of 2 years (2016-17) in a split-split plot design. The genotypes comprised open pollinated cultivars Bull's Blood and Touchstone Gold, and F1 hybrid Merlin (all from Johnny's Selected Seeds, Albion, ME), plus the inbred line W357B from the University of Wisconsin table beet breeding program (Goldman, 1996). 'Bull's Blood' and 'Touchstone Gold' possess characteristically high and low geosmin levels, respectively, while 'Merlin' has intermediate geosmin concentration (Freidig and Goldman, 2014); no previous geosmin levels have been measured for 'W357B'. Sites were selected for differing soil types and CEC: soil at Hancock Agricultural Research Station (HARS, Hancock, WI) is Plainfield sand with an average CEC of $1.3 \mathrm{cmol}_{\mathrm{c}} \cdot \mathrm{kg}^{-1}$, while soil at West Madison Agricultural Research Station (WMARS, Verona, WI) is Griswold loam and Kegonsa silt loam with an average CEC of $16 \mathrm{cmol}_{\mathrm{c}} \cdot \mathrm{kg}^{-1}$. Temperature and precipitation data were recorded at HARS and at the National Oceanic and Aeronautic Association (NOAA) Charmany Farm weather station (Dane County, WI), located $5 \mathrm{~km}$ west of WMARS.

Four site $\times$ year combinations served as whole plots, each containing three blocks. Each block was divided into two equally sized split plots, which served as experimental units for two fertilizer treatments. Fertilizer treatments were randomly assigned to split plots within each block, yielding three replicates per whole plot. Each split plot was divided into four split-split plots, which served as experimental units for genotypes. Each split-split plot consisted of four 3.7-m rows at 46-cm spacing, and roots were harvested from the center two rows only. All four genotypes were applied to each split plot in random order, such that genotypes were replicated six times in each whole plot. Buffer rows of table beet cultivar Early Wonder Tall Top were planted around the perimeter of each whole plot, extending at least $3.7 \mathrm{~m}$ in all directions.

Soil physical and chemical properties were measured before planting in both 2016 and 2017. Each block at each site was sampled, for a total of three samples per whole plot. Soil chemical properties assessed were $\mathrm{pH}$ (1:1 in water), $\mathrm{NO}_{3}{ }^{-}$, Bray-1 $\mathrm{P}$ and $\mathrm{K}$
(Bray and Kurtz, 1945), exchangeable cations $\mathrm{Ca}^{2+}, \mathrm{Mg}^{2+}, \mathrm{K}^{+}$, and $\mathrm{Na}^{+}$, and CEC (Warncke and Brown, 1982), and hot water extractable B (Watson, 1998). Soil organic matter via loss on ignition was measured in 2016 only. To measure the effect of fertilizer treatment on split plots, each split plot was sampled three times over the growing season (at planting, 7 weeks after planting, and at harvest) for soil cations $\mathrm{Mg}^{2+}, \mathrm{Ca}^{2+}$ (Warncke and Brown, 1982), and $\mathrm{Cu}^{2+}$ (Lindsay and Norvell, 1978). Each sample consisted of eight cylindrical soil cores having a $15 \mathrm{~cm} \times 2.5$ $\mathrm{cm}$ diameter, distributed equally over the block or split plot, using the recommended $\mathrm{W}$-shaped sampling pattern (Peters and Laboski, 2013). To investigate plant uptake of soil cations, leaf tissue $\mathrm{Mg}^{2+}$ and $\mathrm{Ca}^{2+}$ concentration was measured from 'Merlin' plots at both Hancock and Madison twice during 2017. At 7 weeks after planting and at harvest, samples were collected from six plots of 'Merlin' per site; each sample comprised 20 newly expanded mature leaves taken from different plants, and leaves were air dried before analysis (Kelling et al., 2002). All soil and leaf tissue analyses were carried out at the University of Wisconsin Soil and Forage Analysis Laboratory (Marshfield, WI).

Fertilizer treatments were applied immediately before planting, which occurred at Hancock on 1 June 2016 and 2 June 2017, and at Madison on 3 June 2016 and 1 June 2017. One randomly assigned split plot within each block received $\mathrm{MgSO}_{4} \cdot \mathrm{H}_{2} \mathrm{O}$ fertilizer (Magnesium 36\% Granular Oxysulfate; Cameron Chemicals, Portsmouth, VA) at the rate of $0.9 \mathrm{~kg}$ per split plot $\left(120 \mathrm{~kg} \cdot \mathrm{ha}^{-1} \mathrm{Mg}\right)$, with a goal of increasing free soil $\mathrm{Mg}^{2+}$ to $100 \mathrm{mg} \cdot \mathrm{kg}^{-1}$ on the low-CEC soil at Hancock. Calcium sulfate (SuperCal $\mathrm{SO}_{4}$ Pelletized Gypsum; Calcium Products, Ames, IA) was applied to the other split plot of each block at a rate of $0.23 \mathrm{~kg}$ per split plot $\left(26.8 \mathrm{~kg} \cdot \mathrm{ha}^{-1} \mathrm{Ca}\right)$ to equalize $\mathrm{SO}_{4}$ contribution to the soil and to provide $\mathrm{Ca}^{2+}$ as a competing cation for $\mathrm{Mg}^{2+}$. Pelletized $5 \mathrm{~N}-0.8 \mathrm{P}-0 \mathrm{~K}$ organic fertilizer (Milorganite, Milwaukee, WI) was used as a carrier for both experimental fertilizers. Preemergent herbicide applications of 0.8 $\mathrm{L} \cdot \mathrm{ha}^{-1} \mathrm{~S}$-metolachlor (Dual Magnum; Syngenta, Greensboro, NC) and $2.4 \mathrm{~L} \cdot \mathrm{ha}^{-1}$ ethofumesate (Nortron SC; Bayer Crop Science, Research Triangle Park, NC) were made on all plots. Standard crop fertility was maintained per HARS and WMARS practices. No supplementary fertilizer was needed on Madison's silt loam soil, but Hancock's sandy soil required annual application of $61.7 \mathrm{~kg} \cdot \mathrm{ha}^{-1} \mathrm{~N}$ via fertigation, plus granular boron and phosphorous fertilizer at the University of Wisconsin Cooperative Extension's recommended rates (Laboski and Peters, 2012). Plots were hand weeded as needed, and seedlings were thinned to $\approx 3.5-\mathrm{cm}$ spacing about 6 weeks after planting. Harvest was carried out 12 to 13 weeks after planting, on 29 Aug. 2016 and 25 Aug. 2017 at Hancock and on 30 Aug. 2016 and 23 Aug. 2017 at Madison.

RoOT GRADING AND SAMPLING. At least 20 roots of diverse sizes were harvested by hand from each split-split plot when available. Roots were graded within $2 \mathrm{~d}$ of harvest, and five roots of 2.5 to $6 \mathrm{~cm}$ diameter were selected, dry-brushed to remove soil, cut in half from taproot to crown, and positioned cut-side down for sampling. A cylindrical core borer with $1 \mathrm{~cm}$ diameter was inserted into the thickest part of each halved root, and a cylinder with uniform epidermal area and varying length was extracted. One cylindrical core was taken from each halved root, for a bulked tissue sample of 10 cores per split-split plot.

To further investigate the effect of root size on geosmin concentration, five roots in each of three diameter grades $(<2.5$, $2.5-6$, and $>6 \mathrm{~cm}$ ) were selected from each 'Merlin' split-split plot in 2016, and a 10-core bulked sample was taken from each size grade as described above. 'Merlin' was selected for analysis by root 
size because it showed less variation in geosmin concentration between field and greenhouse environments than other commercial cultivars (Freidig and Goldman, 2014). The present study standardized root size across genotypes and environments rather than adding root size as an additional factor in the experimental design, so significant variation in geosmin concentration by root size in 'Merlin' - a genotype documented as less variable than other commercial cultivars - would serve to justify standardization of root size. Finally, to measure root-to-root geosmin variability, 10 individual roots of 2.5 to $6 \mathrm{~cm}$ diameter were sampled from one split-split plot of each genotype in both 2016 and 2017. An individual root sample comprised at least six cores from a single root. All samples were stored immediately at $-80{ }^{\circ} \mathrm{C}$.

LABORATORY ANALYSIS. Frozen core samples were held at $-20{ }^{\circ} \mathrm{C}$ and then thawed 5 to $10 \mathrm{~min}$ before processing. From each 10-core sample, six cores with complete epidermal disks were selected, and internal root tissue was trimmed until the sample mass reached $30 \mathrm{~g}$. Milli-Q water (Millipore, Bedford, MA) was added at a 1:1 ratio, and samples were blended for 2 min using an industrial blender. Homogenate and remaining root tissue were both stored at $-20{ }^{\circ} \mathrm{C}$.

Geosmin concentration was measured by HSPME and GCMS using the method described by Maher and Goldman (2017, 2018), adapted from Lu et al. (2003b). Homogenate was thawed briefly in a $32{ }^{\circ} \mathrm{C}$ water bath, only until stirring was possible; $5 \mathrm{~g}$ homogenate was combined with $1 \mathrm{~g} \mathrm{NaCl}$ in a screw-top glass vial, which was sealed immediately with a cap containing a polytetrafluoroethylene (PTFE)-silicone septum. A water blank and three geosmin standards of Milli-Q water with 5, 10, and $21.6 \mu \mathrm{g} \cdot \mathrm{kg}^{-1} \pm(-)$ geosmin (Sigma-Aldrich, St. Louis, MO) were included with each GC-MS cycle for calibration curve construction. An internal standard, -(-)menthone (SigmaAldrich), was injected at the concentration of $2.82 \mu \mathrm{g}$ geosmin per kilogram root tissue in all table beet samples and geosmin standards. Relative recovery ( $R R$ in Eq. [1]) was calculated by comparing geosmin concentration in unmodified table beet homogenate with that in identical homogenate spiked with 5 , 10,15 , and $21.6 \mu \mathrm{g} \cdot \mathrm{kg}^{-1}$ geosmin, according to the calculation originated by Lu et al. (2003b):

$$
R R=\frac{\mu g \text { Geosmin }_{\text {Total }}-\mu g \text { Geosmin }_{\text {Unmodified }}}{\mu g \text { Geosmin }_{\text {Spiked }}} \times 100 \% .
$$

This equation quantifies the proportion of added geosmin that was recovered using the GC-MS protocol. Relative recovery was $37.16 \%$ in 2016 and $40.37 \%$ in 2017.

Volatile analysis using HSPME and GC-MS followed the protocol of Maher and Goldman (2017), using GC-MS (QP2010SE; Shimadzu, Kyoto, Japan) with an autoinjector (AOC-5000, Shimadzu). Samples were incubated at $60{ }^{\circ} \mathrm{C}$ for $3 \mathrm{~min}$ with simultaneous agitation at $500 \mathrm{rpm}$. Volatiles were extracted onto a polydimethylsiloxane/divinylbenzene (PDMS/DVB) fiber (Supelco, Bellefonte, PA) for 10 min under identical temperature and agitation conditions. The fiber was thermally desorbed into the GC-MS for $1 \mathrm{~min}$ at $250^{\circ} \mathrm{C}$ using split injection mode with split ratio 10 and a split/splitless liner (Restek, Bellefonte, PA). Samples were passed through a $30-\mathrm{m}$ MS column with $0.25 \mathrm{~mm}$ i.d. and $0.25 \mu \mathrm{m}$ df (SH-Rxi-5Sil, Shimadzu). Temperature was held at $40{ }^{\circ} \mathrm{C}$ for $1 \mathrm{~min}$, increased to $300{ }^{\circ} \mathrm{C}$ at a rate of $35^{\circ} \mathrm{C} \cdot \mathrm{min}^{-1}$, and held for $2 \mathrm{~min}$. Fibers were conditioned for $10 \mathrm{~min}$ at $250{ }^{\circ} \mathrm{C}$ between samples.
To measure TDS, tissue remaining from each sample after GC-MS homogenate preparation was thawed in a $40{ }^{\circ} \mathrm{C}$ water bath and transferred to a petri dish. Thawed root cores were pressed with a glass weight to expel liquid. We placed $100 \mu \mathrm{L}$ liquid on the stage of an ABBE-3L refractometer (Thermo Fisher Scientific, Waltham, MA), and TDS was read according to manufacturer instructions.

Statistical Analysis. Mixed-model analysis of variance (ANOVA) was carried out using PROC MIXED in SAS (version 9.4; SAS Institute, Cary, NC) according to the linear model:

$$
\begin{aligned}
R_{h i j k l}= & \mu+Y_{h}+S_{i}+(Y S)_{h i}+\beta_{j}(Y S)_{h i}+F_{k} \\
& +(Y F)_{h k}+(S F)_{i k}+(Y S F)_{h i k}+\varepsilon_{h i j k}+G_{l}+(Y G)_{h l} \\
& +(S G)_{i l}+(F G)_{k l}+(Y S G)_{h i l}+(Y F G)_{h k l}+(S F G)_{i k l} \\
& +(Y S F G)_{h i k l}+\delta_{h i j k l}
\end{aligned}
$$

Separate analyses were made for response variables $(R)$ geosmin concentration and TDS. Year $(Y)$, site $(S)$, fertilizer $(F)$, and genotype $(G)$ were treated as fixed effects with indices $h, i, k$, and $l$, respectively. Whole plot error $\left[\beta_{j}(Y S)_{h i}\right.$, the effect of block with index $j$ nested in year $\times$ site combination] and split plot error $\left(\varepsilon_{h i j k}\right.$, the interaction of whole plot error with fertilizer treatment) were defined as random. Residual error between split-split plots was represented by $\delta_{h i j k l}$.

For estimation of repeatability using variance components (Eq. [2]), all terms were defined as random. RStudio 1.0.153 (RStudio, Boston, MA) and R 3.4.1 (R Core Team, Vienna, Austria) were used for supplemental data analysis and graphics, including analysis of variation in geosmin concentration and TDS between roots and according to root size, and analysis of soil parameters. Tukey-Kramer correction was used for all pairwise comparisons of means.

Repeatability, here estimated identically to broad-sense heritability $(H)$, measures the proportion of total phenotypic variance attributable to genotypic variance. It is calculated with variance components from random model ANOVA, using split-split plot means across multiple years, sites, and fertilizer treatments, after Holland et al. [2003 (Table 2.1.2.D)], where $Y, S, F, G$, and $B$ represent year, site, fertilizer treatment, genotype, and block, respectively. The number of year, site, fertilizer, and block treatments are given by $y, s, f$, and $b$.

$$
\hat{H}=\frac{\hat{\sigma}_{G}^{2}}{\hat{\sigma}_{G}^{2}+\frac{\hat{\sigma}_{G Y}^{2}}{y}+\frac{\hat{\sigma}_{G S}^{2}}{s}+\frac{\hat{\sigma}_{G Y S}^{2}}{y s}+\frac{\hat{\sigma}_{G F}^{2}}{f}+\frac{\hat{\sigma}_{G Y F}^{2}}{y f}+\frac{\hat{\sigma}_{G S F}^{2}}{s f}+\frac{\hat{\sigma}_{G Y S F}^{2}}{y s f}+\frac{\hat{\sigma}_{G Y S F}^{2}}{y s f}+\frac{\hat{\sigma}_{\varepsilon}^{2}}{y s f b}}
$$

True broad-sense heritability is calculated using randomly drawn genotypes from a population of interest and multiple, representative sites from the target population of environments (Holland et al., 2003). Because this experiment uses a nonrandom set of genotypes and sites, the broad sense heritability estimate is termed "repeatability" to emphasize that it applies only to the small set of genotypes and environments studied. "Repeatability" in this study should not be confused with the 
repeatability statistic that quantifies error associated with multiple measurements of the same individual as explicated by Falconer and Mackay (1996).

\section{Results}

Analysis of variance revealed that a strong genotype effect, in addition to significant genotype $\times$ year and year $\times$ site interactions, accounted for variation in table beet geosmin concentration (Table 1). While a significant genotype main effect was also present for TDS, it occurred in the context of significant four-way and three-way interactions of genotype $\times$ fertilizer $\times$ year $\times$ site and genotype $\times$ fertilizer $\times$ site, respectively. TDS also varied significantly with year, year $\times$ site interaction, and split plot error, which represents variation among split blocks of like fertilizer treatment, nested within whole plot. Thus, blocking was effective in absorbing variation in TDS on the split plot level that would otherwise have been attributed to fertilizer $\times$ year $\times$ site interaction. Split plot error was not significant with respect to geosmin concentration; whole plot error was not significant for either flavor compound. Notably, neither geosmin concentration nor TDS was significantly influenced by fertilizer treatment or fertilizer $\times$ environment interactions, averaged across genotypes.

While a significant main effect of genotype on geosmin concentration was present, this effect must be interpreted in context of its interaction with year. The significant genotype $\times$ year interaction for geosmin concentration (Fig. 1) was effectively of a non-crossover nature and driven by the distinct

Table 1. Degrees of freedom (df) and $F$ statistics from ANOVA on split-split plot design for effects of year, site, fertilizer (F), and genotype on geosmin concentration and total dissolved solids in four table beet cultivars grown at two sites over 2 years in Wisconsin. Whole plot, split plot, and split-split plot factors are tested against the respective error terms (shaded).

\begin{tabular}{|c|c|c|c|c|}
\hline \multirow[b]{2}{*}{ Source } & \multicolumn{2}{|c|}{ Geosmin } & \multicolumn{2}{|c|}{ Total dissolved solids } \\
\hline & $\mathrm{df}$ & $\mathrm{F}$ & $\mathrm{df}$ & $\mathrm{F}$ \\
\hline \multicolumn{5}{|l|}{ Whole plot } \\
\hline Year (Y) & 1 & 1.28 & 1 & $6.28 *$ \\
\hline Site $(\mathrm{S})$ & 1 & 0.49 & 1 & 2.95 \\
\hline $\mathrm{Y} \times \mathrm{S}$ & 1 & $14.88 * *$ & 1 & $10.11^{*}$ \\
\hline $\mathrm{Y} \times \mathrm{S} \times$ Block $(\mathrm{B})$ & 8 & 0.43 & 8 & 0.94 \\
\hline \multicolumn{5}{|l|}{ Split plot } \\
\hline Fertilizer $(\mathrm{F})$ & 1 & 0.09 & 1 & 0.14 \\
\hline $\mathrm{Y} \times \mathrm{F}$ & 1 & 0.2 & 1 & 0.32 \\
\hline $\mathrm{S} \times \mathrm{F}$ & 1 & 0.12 & 1 & 1.22 \\
\hline $\mathrm{Y} \times \mathrm{S} \times \mathrm{F}$ & 1 & 0.03 & 1 & 2.14 \\
\hline $\mathrm{Y} \times \mathrm{S} \times \mathrm{B} \times \mathrm{F}$ & 8 & 1.41 & 8 & $2.42 *$ \\
\hline \multicolumn{5}{|l|}{ Split-split plot } \\
\hline Genotype (G) & 3 & $68.76^{* * *}$ & 3 & $4.66^{* *}$ \\
\hline $\mathrm{Y} \times \mathrm{G}$ & 3 & $6.05 * *$ & 3 & 0.53 \\
\hline $\mathrm{S} \times \mathrm{G}$ & 3 & 0.4 & 3 & 1.55 \\
\hline $\mathrm{Y} \times \mathrm{S} \times \mathrm{G}$ & 3 & 1.04 & 3 & 1.8 \\
\hline $\mathrm{F} \times \mathrm{G}$ & 3 & 0.19 & 3 & 0.61 \\
\hline $\mathrm{Y} \times \mathrm{F} \times \mathrm{G}$ & 3 & 0.62 & 3 & 1.25 \\
\hline $\mathrm{S} \times \mathrm{F} \times \mathrm{G}$ & 3 & 0.57 & 3 & $4.73 * *$ \\
\hline $\mathrm{Y} \times \mathrm{S} \times \mathrm{F} \times \mathrm{G}$ & 3 & 0.18 & 3 & $3.75^{*}$ \\
\hline Residual & 48 & & 45 & \\
\hline
\end{tabular}

*,**,***Significant at $P \leq 0.05,0.01$, or 0.001 , respectively. character of 'Bull's Blood', a known high geosmin cultivar (Freidig and Goldman, 2014). 'Bull's Blood' ranked first for geosmin concentration in both 2016 and 2017, and its mean geosmin concentration in both years was significantly higher than means of all other cultivars in both years (all pairwise comparisons $P<0.001$ ). Two of the three remaining cultivars changed rank nominally between 2016 and 2017, but no significant differences were found in pairwise comparisons of 'Merlin', 'Touchstone Gold', and 'W357B' mean geosmin concentrations, either within or between years. Because the second-, third-, and fourth-ranked cultivars showed statistically equal geosmin concentration between years, they did not contribute to the significant genotype $\times$ year interaction $(P<$ 0.01). This interaction was driven wholly by 'Bull's Blood', which showed significantly different geosmin concentration between years $(P<0.01)$.

The strongly significant genotype main effect $(P<0.0001)$ for geosmin concentration was also completely due to the increased mean of 'Bull's Blood' (Fig. 2, Table 2). 'Bull's Blood' geosmin concentration, averaged across years and sites, was significantly higher than that of 'Merlin', 'Touchstone Gold', and 'W357B' $(P<0.0001)$, and no significant differences were found between means of the latter three cultivars. Analysis of 10 individual roots per genotype $\times$ year combination revealed similar trends in geosmin concentration and variability. Mean individual-root geosmin concentration was significantly higher for 'Bull's Blood' in both 2016 and 2017 than for all other genotype $\times$ year individual root means $(P<$ 0.001 ), with standard error 3- to 4-fold higher for 'Bull's Blood' than for the other cultivars (Supplemental Fig. 1A, Supplemental Table 1). Thus, cultivar specificity was demonstrated for geosmin concentration and variability, both in bulked five-root samples and individual-root samples. Repeatability was 0.90 for geosmin concentration, quantifying the large contribution of genotypic variation to total variation in geosmin concentration in this set of table beet genotypes.

Finally, the observed year $\times$ site interaction for geosmin concentration was significant $(P<0.01)$ and of crossover nature, with higher mean geosmin concentration at Madison in 2016 and at Hancock in 2017. However, the Tukey-Kramercorrected year $\times$ site means, averaged over cultivars, were not significantly different within or between years (data not shown). While genotype $\times$ year interaction was driven by the high concentration and variability of geosmin in 'Bull's Blood', the absence of significant genotype $\times$ site interaction precludes us from attributing the year $\times$ site interaction to the high geosmin character of 'Bull's Blood'.

To investigate the effect of root size on geosmin concentration, twelve bulked five-root samples of 'Merlin' from each of three size grades were collected from Hancock and Madison in 2016. ANOVA showed a significant effect of size grade $\left(P<0.05, F_{2,33}=3.76\right)$, and roots with a diameter less than $2.5 \mathrm{~cm}$ showed significantly lower mean geosmin concentration than roots with a diameter greater than $6 \mathrm{~cm}$ $(P<0.05)$.

While variation in geosmin concentration was explained by a few relatively simple trends, variation in TDS involved complex interactions. Dissection of a four-way genotype $\times$ fertilizer $\times$ year $\times$ site interaction $(P<0.05)$ revealed that all genotypes, under both fertilizer treatments, showed higher TDS at Hancock in 2017 than in 2016 (Supplemental Fig. 2A). This trend did not hold at Madison, where all genotypes showed lower TDS in 2017 


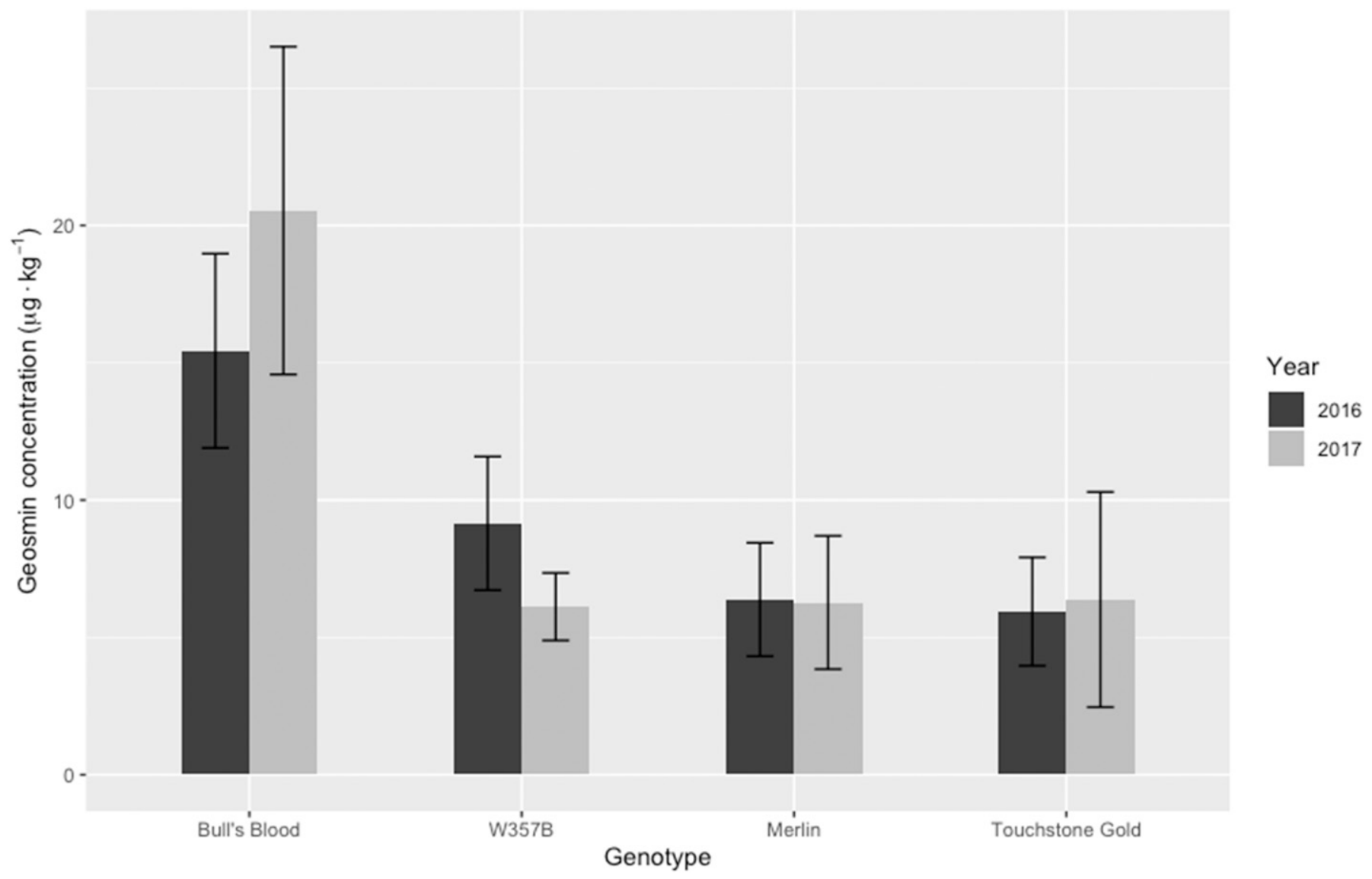

Fig. 1. Genotype $\times$ year interaction for geosmin concentration in four table beet genotypes grown in 2016 and 2017, averaged over two Wisconsin field sites (Hancock, Madison) and two fertilizer treatments. Error bars show \pm 1 SE of raw data.
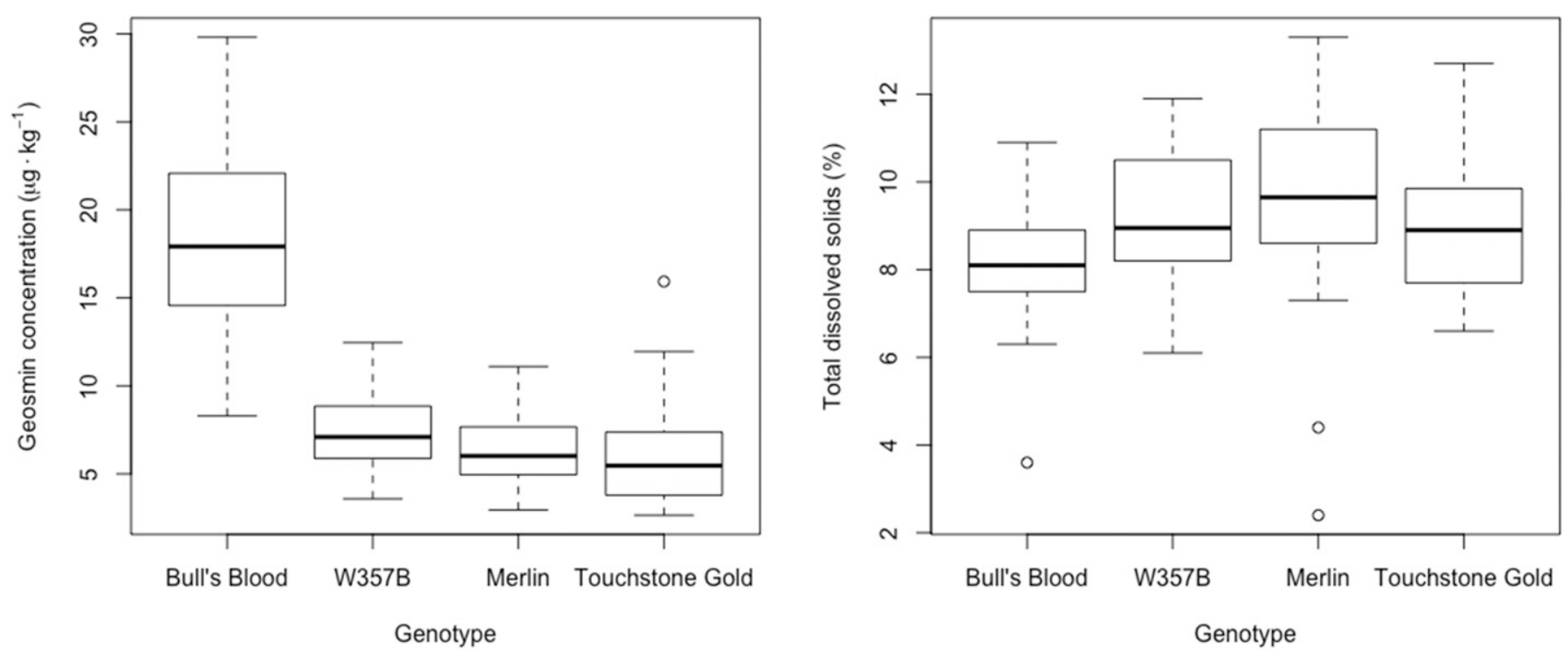

Fig. 2. Box and whisker plot showing genotype median geosmin concentration and total dissolved solids of three table beet cultivars (Bull's Blood, Merlin, and Touchstone Gold) and one inbred line (W357B) averaged over two Wisconsin field sites (Hancock, Madison) and 2 years (2016, 2017).

under the calcium fertilizer treatment, and crossover interaction was observed under the magnesium fertilizer treatment. However, no pairwise comparisons at either site were significant after Tukey-Kramer correction. Thus, while this four-way interaction suggests that the Hancock 2017 environment facilitated TDS accumulation in table beet more than did the Hancock 2016 environment, the small magnitude and variable nature of the TDS differences limit the insight offered by this interaction. The 
Table 2. Genotype mean geosmin concentration and total dissolved solids (TDS) of three table beet cultivars (Bull's Blood, Merlin, and Touchstone Gold) and one inbred line (W357B) grown at two Wisconsin field sites (Hancock, Madison) in 2016 and 2017.

\begin{tabular}{lcclc}
\hline & Bull's Blood & W357B & Merlin & Touchstone Gold \\
\hline Geosmin $\left(\mu \mathrm{g} \cdot \mathrm{kg}^{-1}\right)$ & $18.00 \mathrm{a}^{\mathrm{z}}$ & $7.64 \mathrm{~b}$ & $6.33 \mathrm{~b}$ & $6.16 \mathrm{~b}$ \\
TDS $(\%)$ & $8.2 \mathrm{a}$ & $9.2 \mathrm{ab}$ & $9.5 \mathrm{~b}$ & $8.8 \mathrm{ab}$
\end{tabular}

${ }^{\mathrm{z}}$ Different letters within the row denote significant difference in genotype means at $P \leq 0.05$ after Tukey-Kramer correction.

significant three-way genotype $\times$ fertilizer $\times$ site interaction $(P<$ $0.01)$ was of a crossover nature and suggests neither specific cultivars nor environmental conditions that were consistently associated with TDS accumulation (Supplemental Fig. 2B). However, these complex genotype $\times$ environment interactions do provide evidence of environmental influence on variation in TDS in table beet.

The small but significant year $\times$ site interaction and year main effects (both $P<0.05$ ) provide further evidence of environmental contribution to variation in TDS. The year $x$ site interaction was of crossover nature and showed that mean TDS, averaged over all cultivars, was significantly higher at Hancock in 2017 than in all other year $\times$ site combinations $(P<$ 0.05 for each pairwise comparison). This interaction drove the year main effect $(P<0.05)$ of higher TDS in 2017 than 2016, averaged across locations.

Genetic influence on TDS variation was also apparent, as demonstrated by a significant genotype main effect $(P<0.01)$. Mean TDS in 'Merlin' was significantly higher than in 'Bull's Blood' $(P<0.01)$, while 'Touchstone Gold' and 'W357B' showed intermediate mean TDS that was not significantly different from either 'Merlin' or 'Bull's Blood' (Fig. 2, Table 2). Analysis of 10 individual roots from each genotype $\times$ year combination supports the notion that environmental and genetic factors interact to determine variation in TDS. That is, mean TDS between years for 'Bull's Blood' and 'Touchstone Gold' was significantly different $(P<0.05$ and $P<0.01$, respectively), while mean TDS for 'W357B' and 'Merlin' was statistically equal between years (Supplemental Fig. 1B, Supplemental Table 1). Repeatability for TDS was 0.43 , demonstrating the moderate contribution of genotype to overall variation in TDS for these specific cultivars.

The silt loam soil at Madison showed significantly higher $\mathrm{pH}, \mathrm{NO}_{3}{ }^{-}, \mathrm{K}_{\mathrm{Ca}^{2+}}, \mathrm{Mg}^{2+}, \mathrm{CEC}, \mathrm{B}$, and organic matter than the sand at Hancock before planting in both 2016 and 2017; phosphorous was the only soil characteristic that did not differ significantly between sites (Table 3 ). The magnitude of $\mathrm{pH}$, $\mathrm{NO}_{3}{ }^{-}, \mathrm{P}, \mathrm{Ca}^{2+}, \mathrm{CEC}$, and density varied significantly with year, but the significant year $\times$ site interactions observed for $\mathrm{NO}_{3}^{-}, \mathrm{K}$, $\mathrm{Ca}^{2+}$, and CEC were of non-crossover nature. While absolute concentrations of $\mathrm{Ca}^{2+}$ and $\mathrm{Mg}^{2+}$ were significantly different between sites, the $\mathrm{Ca}^{2+}: \mathrm{Mg}^{2+}$ ratio was about equal between sites, at about 3:1. Although soil exchangeable $\mathrm{Ca}^{2+}$ and $\mathrm{Mg}^{2+}$ concentration was significantly higher at Madison than Hancock both at midseason and at harvest, $\mathrm{Ca}^{2+}$ and $\mathrm{Mg}^{2+}$ concentration in 'Merlin' leaf tissue did not reflect this pattern. Instead, leaf tissue $\mathrm{Ca}^{2+}$ concentration was significantly lower at Madison than Hancock at midseason and showed no significant difference at harvest; leaf tissue $\mathrm{Mg}^{2+}$ concentration was statistically equal between sites at midseason but lower at Madison than Hancock at harvest (Supplemental Table 2).
Fertilizer treatment did not significantly change soil $\mathrm{Ca}^{2+}$, $\mathrm{Mg}^{2+}$, or $\mathrm{Cu}^{2+}$ concentration on split plots from preapplication levels (data not shown). Similarly, 2017 'Merlin' leaf tissue samples from both fertilizer treatment groups showed no significant difference in magnesium or calcium concentration (Supplemental Table 2). Thus, it appears that while fertilizer treatment neither altered soil cation content nor plant tissue cation content, the divergent soil types at Madison and Hancock provided substantially different physicochemical environments for plant growth.

Mean daily temperature from 1 June to 30 Aug. was 0.4 and $1{ }^{\circ} \mathrm{C}$ cooler at Hancock than Madison in 2016 and 2017, respectively. Considering both rainfall and irrigation, both sites received 10\% more water in 2017 than 2016, while Hancock received 36\% more water than Madison in both years (Supplemental Table 3). However, soil water-holding capacity differs greatly between the sand and silt loam of Hancock and Madison, respectively, so total water application does not necessarily reflect the soil's water content or the plants' water availability.

\section{Discussion}

This experiment characterized the relative genetic and environmental contributions to phenotypic variance in two flavor compounds essential to the sensory experience of table beet: geosmin and sucrose (measured as TDS). Genetics determined a larger proportion of variance for geosmin concentration than TDS in the four table beet genotypes assessed, as reflected in repeatability measurements of 0.90 and 0.43 , respectively. Because this experiment used a small, nonrandom set of cultivars, these statistics cannot be used to infer broad-sense heritability for all table beet accessions. However, taken in context of existing knowledge about geosmin concentration and TDS in B. vulgaris, this experiment provides support for the primacy of genotype in determining table beet geosmin concentration and a lesser role for genotype in determining table beet TDS.

Table beet genotypes in this experiment were observed to have characteristic geosmin concentration and variance, despite being grown in soils with widely divergent physical and chemical properties. That is, the observed genotype $\times$ year effect was due solely to the relatively high variance of geosmin concentration in 'Bull's Blood', a cultivar previously characterized as high in geosmin (Freidig and Goldman, 2014). Maher and Goldman (2018) had previously described the phenomenon illustrated by 'Bull's Blood' in this experiment: that variability in geosmin concentration increases with the concentration itself. The cultivar specificity of both geosmin concentration and its variability was unaffected by growth in dramatically different soil environments. Madison's silt loam offered significantly greater $\mathrm{pH}$, macronutrient availability, soil organic matter, cation concentration, CEC, and water-holding capacity than Hancock's sandy soil (Table 3). In addition, the availability of routine irrigation at Hancock allowed for less water stress in that environment. If geosmin concentration in table beet were substantially influenced by environmental factors, it is plausible that these two environments would have generated statistically significant site effects or genotype $\times$ site interactions. However, neither of these effects were observed; instead, evidence accrued for the paramount role of genotype in determining table beet geosmin concentration.

While Freidig and Goldman (2014) found highly significant genotype effects for geosmin concentration in a study comparing 
Table 3. Soil $\mathrm{pH}$, macronutrients $\left(\mathrm{N}\right.$ as $\left.\mathrm{NO}_{3}^{-}, \mathrm{P}, \mathrm{K}\right)$ cations $\left(\mathrm{Ca}^{2+}, \mathrm{Mg}^{2+}\right)$, cation exchange capacity (CEC), boron, density, and organic matter (OM) at two Wisconsin field sites (Hancock, Madison) in 2016 and 2017. Asterisks denoting significance apply to analysis of variance for each soil characteristic by site, year, and year-site interaction.

\begin{tabular}{|c|c|c|c|c|c|c|c|}
\hline & \multicolumn{2}{|c|}{ Hancock } & \multicolumn{2}{|c|}{ Madison } & \multicolumn{3}{|c|}{ Significance } \\
\hline & 2016 & 2017 & 2016 & 2017 & $\overline{\text { Site }}$ & $\mathrm{Yr}$ & Site $\times$ Yr \\
\hline$\overline{\mathrm{pH}}$ & $5.6 \mathrm{a}^{\mathrm{z}}$ & $5.7 \mathrm{a}$ & $6.5 \mathrm{~b}$ & $6.9 \mathrm{c}$ & $* * *$ & $*$ & \\
\hline $\mathrm{NO}_{3}-\mathrm{N}\left(\mathrm{mg} \cdot \mathrm{kg}^{-1}\right)$ & $8.2 \mathrm{a}$ & $6.8 \mathrm{a}$ & $32.0 \mathrm{~b}$ & $20.4 \mathrm{c}$ & $* * *$ & $* * *$ & $* * *$ \\
\hline $\mathrm{P}\left(\mathrm{mg} \cdot \mathrm{kg}^{-1}\right)$ & $29 \mathrm{a}$ & $63 \mathrm{~b}$ & $45 \mathrm{ab}$ & $113 \mathrm{c}$ & & $* *$ & \\
\hline $\mathrm{K}\left(\mathrm{mg} \cdot \mathrm{kg}^{-1}\right)$ & $97 \mathrm{a}$ & $61 \mathrm{a}$ & $226 \mathrm{~b}$ & $287 \mathrm{~b}$ & $*$ & & $*$ \\
\hline $\mathrm{Ca}^{2+}\left(\mathrm{mg} \cdot \mathrm{kg}^{-1}\right)$ & $251 \mathrm{a}$ & $225 \mathrm{a}$ & $2090 \mathrm{~b}$ & $1757 \mathrm{c}$ & $* * *$ & $* *$ & $* *$ \\
\hline $\mathrm{Mg}^{2+}\left(\mathrm{mg} \cdot \mathrm{kg}^{-1}\right)$ & $72 \mathrm{a}$ & $67 \mathrm{a}$ & $551 \mathrm{~b}$ & $620 \mathrm{c}$ & $* * *$ & & \\
\hline $\mathrm{CEC}\left(\mathrm{cmol}_{\mathrm{c}} \cdot \mathrm{kg}^{-1}\right)$ & $1.3 \mathrm{a}$ & $1.0 \mathrm{a}$ & $16.0 \mathrm{~b}$ & $13.3 \mathrm{c}$ & $* * *$ & $* *$ & $* *$ \\
\hline $\mathrm{B}\left(\mathrm{mg} \cdot \mathrm{kg}^{-1}\right)$ & $0.2 \mathrm{a}$ & $0.17 \mathrm{a}$ & $0.77 \mathrm{~b}$ & $0.83 \mathrm{~b}$ & $* * *$ & & \\
\hline Density $\left(\mathrm{g} \cdot \mathrm{cm}^{-3}\right)$ & $1.41 \mathrm{a}$ & $1.48 \mathrm{~b}$ & $0.98 \mathrm{c}$ & $1.09 \mathrm{~d}$ & $* *$ & $* *$ & \\
\hline OM (\%) & $0.8 \mathrm{a}$ & na & $4.4 \mathrm{~b}$ & na & $* * *$ & na & na \\
\hline
\end{tabular}

$*, * *, * * *$ Significant at $P \leq 0.05,0.01$, or 0.001 , respectively.

${ }^{\mathrm{z}}$ Different letters within the row denote significant difference between site-year combination means at $P \leq 0.05$ after Tukey-Kramer correction.

field- and greenhouse-grown table beets, they also found environmental main effects and non-crossover genotype $\times$ environment interaction. However, while both soil characteristics and circadian temperature regimes differed between field and greenhouse environments, so did the size of roots evaluated. We observed a statistically significant difference in mean geosmin concentration between 'Merlin' roots with a diameter less than 2.5 $\mathrm{cm}$ and greater than $6 \mathrm{~cm}(P<0.05)$, which shows that geosmin concentration can vary with root size even in a cultivar relatively stable for geosmin concentration (Freidig and Goldman, 2014), and even when the root sampling method standardizes the ratio of epidermal to core root tissue analyzed. Thus, differential root size could have contributed significantly to the environmental effect and genotype $\times$ environment interaction observed by Freidig and Goldman (2014). Importantly, Freidig and Goldman found a significant genotype effect for geosmin concentration, even though the root size difference generated by field vs. protected culture could have magnified environmental and genotype $x$ environment interaction effects. This lends further support for the primary importance of genotype in determining geosmin concentration in table beet. In addition, we note that because it is plausible that genotype $\times$ root size interaction exists with respect to geosmin concentration in table beet, this study's results apply only to medium-sized roots of the four genotypes assessed.

Repeatability for geosmin concentration, calculated to be 0.90 in this experiment, is higher than the realized heritabilities calculated from recurrent selection by Maher and Goldman (2017): 0.70 and 0.23 for low and high geosmin populations, respectively. However, this difference is to be expected, as repeatability is calculated from a randomized, replicated experimental design that allows mathematical accounting for environmental variability over both time and space. In contrast, recurrent selection inherently occurs over successive years with unreplicable growing conditions, so it is impossible to parse year-to-year environmental variability from genetic gain from selection.

The genotype specificity and repeatability of geosmin concentration provide strong evidence for genetic control of this trait. However, knowing that geosmin concentration is largely genetically determined does not elucidate the origin of geosmin in table beet. If the gene(s) controlling this trait produced a root exudate or promoted symbiosis with a geosmin-synthesizing endophyte, geosmin in table beet could plausibly be produced by soil-dwelling or endophytic microbes, respectively. However, given that table beets grown in autoclaved soil (Freidig and Goldman, 2014) and sterile tissue culture (Maher and Goldman, 2018) still produced geosmin, support accrues for the phenomenon of endogenous geosmin biosynthesis in table beet.

While proteins resembling prokaryotic geosmin synthase have been identified using the sugar beet reference genome (Maher, 2017), the function of these proteins has not been validated via gene knockout or transcriptomics. Thus, although general pathways for terpene and sesquiterpene synthesis within gymnosperms and angiosperms are well defined (Dudareva et al., 2013), it is premature to speculate about a hypothetical biosynthetic pathway for geosmin within $B$. vulgaris. When and if a $B$. vulgaris geosmin synthase is validated, it will be appropriate to investigate precursor molecules and rate-limiting steps in table beet geosmin biosynthesis, which may lend insight into the phenomenon that the variability of geosmin concentration increases with geosmin concentration itself.

Because an endogenous $B$. vulgaris geosmin synthase enzyme has not been validated, it cannot be known whether it might require a $\mathrm{Mg}^{2+}$ cofactor like the prokaryotic geosmin synthase. However, such a cofactor requirement remains possible, so $\mathrm{Mg}^{2+}$ supplementation could plausibly affect geosmin concentration in table beet. However, it appears that the $\mathrm{Mg}^{2+}$ and $\mathrm{Ca}^{2+}$ fertilization regimes used in this experiment were ineffective in altering both soil cation concentration and leaf tissue cation concentration. Fertilizer treatment notwithstanding, neither geosmin concentration nor 'Merlin' leaf tissue $\mathrm{Mg}^{2+}$ concentration was affected by soil environments differing in $\mathrm{Mg}^{2+}$ and $\mathrm{Ca}^{2+}$ concentration and CEC by almost an order of magnitude. That is, when 'Merlin' leaf tissue $\mathrm{Mg}^{2+}$ concentration varied significantly between sites, it varied in the opposite direction of soil $\mathrm{Mg}^{2+}$ concentration. Cytosolic magnesium concentration is known to be tightly regulated within B. vulgaris (Shaul, 2002), which would explain the apparent independence of soil $\mathrm{Mg}^{2+}$ concentration from 'Merlin' leaf tissue $\mathrm{Mg}^{2+}$ concentration. However, it is also known that $B$. vulgaris vacuoles store excess $\mathrm{Mg}^{2+}$ (Shaul, 2002), so it is notable that the substantial excess of exchangeable $\mathrm{Mg}^{2+}$ in Madison's soil was not associated with excess $\mathrm{Mg}^{2+}$ in 'Merlin' leaf tissue from Madison. Thus, if $\mathrm{Mg}^{2+}$ does act as a cofactor in endogenous B. vulgaris geosmin biosynthesis, the disconnect between soil $\mathrm{Mg}^{2+}$ concentration and leaf tissue $\mathrm{Mg}^{2+}$ concentration represents a possible mechanism by which environmental influence over geosmin concentration could be limited.

Taken alone, the fact that geosmin did not vary significantly with divergent soil $\mathrm{Mg}^{2+}$ concentration - whether from intrinsic soil characteristics or supplemental fertilizer-supports the relatively minor role of environment in determining geosmin concentration in table beet. Both sites, however, showed $\mathrm{Ca}^{2+}: \mathrm{Mg}^{2+}$ ratios of $\approx 3: 1$. It is possible that significant deviation from this ratio, or a more extreme absolute concentration of $\mathrm{Ca}^{2+}$ or $\mathrm{Mg}^{2+}$ could affect geosmin concentration in table beet. 
That is, it is possible that a critical threshold exists at which the relative or absolute concentration of soil $\mathrm{Ca}^{2+}$ or $\mathrm{Mg}^{2+}$ does affect table beet geosmin concentration. However, we can conclude such a threshold was not reached in the soil environments used in this study. Given the growing body of evidence for predominantly genetic control of geosmin concentration in table beet and the absence of environmental effects in the substantially contrasting soils used in this experiment, genetic rather than cultural manipulation of this trait should be pursued.

In contrast to geosmin, TDS was determined by a complex interplay of genotype and environmental factors. One discernable trend - that of higher mean TDS at Hancock in 2017-emerged from dissection of two significant interactions: genotype $\times$ fertilizer $\times$ year $\times$ site and year $\times$ site. Weather and soil data, however, do not easily explain the higher TDS values observed at Hancock in 2017. Pairwise comparisons between soil characteristics at Hancock in 2016 and 2017 show that only phosphorous concentration was significantly different between the two years. While most soil characteristics were significantly different between Hancock and Madison, these differences were consistent across years. Thus, no soil characteristic is distinctly different at Hancock in 2017 than in other site-year combinations. Examination of a significant threeway genotype $\times$ fertilizer $\times$ site interaction yielded no discernable trends with respect to environmental conditions that might influence TDS in table beet. While the cause of these complex genotype $\times$ environment interactions is inscrutable given the data available, they do demonstrate environmental influence on TDS in table beet. The genotype main effect, in turn, reflects the presence of genetic influence on TDS in table beet.

Repeatability for TDS, calculated to be 0.43 , quantifies the moderate role of genotype in accounting for total variation in this trait. This intermediate level of genetic determination for TDS is consistent with estimated $h^{2}=0.60$ for percent sugar content in sugar beet (Würschum et al., 2011). Realized heritabilities of 0.25 and 0.27 were calculated for TDS in high pigment table beet populations (Wolyn and Gabelman, 1990), but because selection was for an index integrating TDS and betalain pigment concentration, these heritability statistics are not directly comparable to those made for TDS or percent sugar content.

The phenomenon observed in this experiment - of genotype specificity for a volatile compound but significant genotype $\times$ environment interaction for sugar concentration - is not unique to table beet. An even more distinct genotype-dependent aroma profile seems to exist in tomato, as demonstrated in a study comparing tomato flavor in field vs. protected culture. Ten of 12 main tomato aroma compounds varied significantly with genotype, while only two compounds varied between the two environments, and genotype $\times$ environment interaction existed for only one compound. However, the same study showed that fructose and glucose concentration in tomato showed significant genotype, environmental, and interaction effects, with generally lower sugars in protected culture (Cebolla-Cornejo et al., 2011). However, the converse phenomena - significant genotype $\times$ environment interaction with respect to volatile compounds and strong genetic control of sugar concentration - are also documented in studies of potato and strawberry, respectively. That is, a study in potato reported cultivar specificity for several lipid-derived volatiles, Maillard products, and one terpene compound (Duckham et al., 2001), but a subsequent study found a significant environmental effect of storage, and interaction between genotype and storage on many of these compounds (Duckham et al., 2002). In strawberry, a field genotype $\times$ environment experiment showed a strong genotype effect for all measured sugar concentration metrics, although environmental and interaction effects were also present for many sugar parameters (Crespo et al., 2010). Thus, the primacy of genotype in determining volatile concentration and relatively moderate role of genotype in determining sugar concentration appears to be reflected in some, but by no means all, horticultural crops.

While this study confirms existing evidence regarding the moderate role of genotype in determining TDS in table beet, its major contribution is to the establishment of geosmin concentration as a heritable flavor trait in table beet. While table beet geosmin concentration was historically believed to be environmentally determined, a growing body of evidence (Freidig and Goldman, 2014; Lu et al., 2003a; Maher and Goldman, 2017, 2018) has characterized this trait as cultivar specific and heritable. This study is the first field experiment testing the relative importance of genotype, environment, and their interaction on geosmin concentration in mainstream table beet cultivars using standard root size. As such, it serves to confirm and quantify the primacy of genotype in determining concentration of geosmin, the earthy compound that confers the signature flavor of table beet. It also illustrates the previously established phenomenon that variability in geosmin concentration increases with the concentration itself. Breeders can use this newly established understanding of the heritability and variability of geosmin concentration to develop cultivars with characteristic earthiness or even signature flavor profiles. Such cultivars could serve specialty or sourceidentified marketplaces that value distinctive flavor, or they could be targeted toward consumers averse to earthy flavor in table beet, to expand opportunities for both breeders and growers.

\section{Literature Cited}

Acree, T. and C. Lee. 1976. Geosmin, the earthy component of table beet odor. J. Agr. Food Chem. 24:4-5.

Bach, V., L. Mikkelsen, U. Kidmose, and M. Edelenbos. 2015. Culinary preparation of beetroot (Beta vulgaris L.): The impact on sensory quality and appropriateness. J. Sci. Food Agr. 95:1852-1859.

Bray, R.H. and L.T. Kurtz. 1945. Determination of total organic and available forms of phosphorus in soils. Soil Sci. 59:39-45.

Buttery, R.G., D.G. Guadagni, and L.C. Ling. 1976. Geosmin, a musty off-flavor of dry beans. J. Agr. Food Chem. 24:419-420.

Cane, D.E. and R.M. Watt. 2003. Expression and mechanistic analysis of a germacradienol synthase from Streptomyces coelicolor implicated in geosmin biosynthesis. Proc. Natl. Acad. Sci. USA 100:1547-1551. Cebolla-Cornejo, J., S. Roselló, M. Valcárcel, E. Serrano, J. Beltrán, and F. Nuez. 2011. Evaluation of genotype and environment effects on taste and aroma flavor components of Spanish fresh tomato varieties. J. Agr. Food Chem. 59:2440-2450.

Crespo, P., J. Giné Bordonaba, L.A. Terry, and C. Carlen. 2010. Characterisation of major taste and health-related compounds of four strawberry genotypes grown at different Swiss production sites. Food Chem. 122:16-24.

Darriet, P., M. Pons, S. Lamy, and D. Dubourdieu. 2000. Identification and quantification of geosmin, an earthy odorant contaminating wines. J. Agr. Food Chem. 48:4835-4838.

Dawson, J.C. and G.K. Healy. 2018. Flavour evaluation for plant breeders. Plant Breed. Rev. 41:215-261.

Duckham, S.C., A.T. Dodson, J. Bakker, and J.M. Ames. 2001. Volatile flavour components of baked potato flesh. A comparison of eleven potato cultivars. Nahrung 45:317-323.

Duckham, S.C., A.T. Dodson, J. Bakker, and J.M. Ames. 2002. Effect of cultivar and storage time on the volatile flavor components of baked potato. J. Agr. Food Chem. 50:5640-5648.

Dudareva, N., A. Klempien, J.K. Muhlemann, and I. Kaplan. 2013. Biosynthesis, function and metabolic engineering of plant volatile organic compounds. New Phytol. 198:16-32. 
Durrant, M.J. and A.P. Draycott. 1971. Uptake of magnesium and other fertilizer elements by sugar beet grown on sandy soils. J. Agr. Sci. 77:61-68.

Falconer, D.S. and T.F.C. Mackay. 1996. Introduction to quantitative genetics. 4th ed. Pearson Prentice Hall, Harlow, England.

Freidig, A.K. and I.L. Goldman. 2011. Variation in oxalic acid content among commercial table beet cultivars and related crops. J. Amer. Soc. Hort. Sci. 136:54-60.

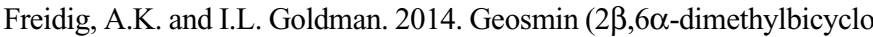
[4.4.0]decan-1 $\beta$-ol) production associated with Beta vulgaris ssp. vulgaris is cultivar specific. J. Agr. Food Chem. 62:2031-2036.

Frisvad, J.C., R.A. Samson, B.R. Rassing, M.I. Van Der Horst, F.T.J. Van Rijn, and J. Stark. 1997. Penicillium discolor, a new species from cheese, nuts and vegetables. Antonie van Leeuwenhoek Intl. J. Genet. Mol. Microbiol. 72:119-126.

Gerber, N.N. 1967. Geosmin, an earthy-smelling substance isolated from actinomycetes. Biotechnol. Bioeng. 9:321-327.

Giglio, S., J. Jiang, C.P. Saint, D.E. Cane, and P.T. Monis. 2008. Isolation and characterization of the gene associated with geosmin production in cyanobacteria. Environ. Sci. Technol. 42:8027-8032.

Goldman, I.L. 1996. A list of germplasm releases from the University of Wisconsin table beet breeding program, 1964-1992. HortScience 31:880-881.

Goldman, I.L. and J.P. Navazio. 2003. History and breeding of table beet in the United States. Plant Breed. Rev. 22:357-388.

Goldman, I.L., K.A. Eagen, D.N. Breitbach, and W.H. Gabelman. 1996. Simultaneous selection is effective in increasing betalain pigment concentration but not total dissolved solids in red beet. $\mathrm{J}$. Amer. Soc. Hort. Sci. 121:23-26.

Grzebisz, W. 2013. Crop response to magnesium fertilization as affected by nitrogen supply. Plant Soil 368:23-39.

Hermans, C., G.N. Johnson, R.J. Strasser, and N. Verbruggen. 2004. Physiological characterisation of magnesium deficiency in sugar beet: Acclimation to low magnesium differentially affects photosystems I and II. Planta 220:344-355.

High Mowing Organic Seeds. 2016. The sweetest beet. 9 Apr. 2019. $<$ https://www.highmowingseeds.com/blog/the-sweetest-beetbasics-of-soil-nutrition/>.

Holland, J.B., W.E. Nyquist, and C.T. Cervantes-Martinez. 2003. Estimating and interpreting heritability for plant breeding: An update. Plant Breed. Rev. 22:9-112.

Jensen, K., M.A. Petersen, L. Poll, and P.B. Brockhoff. 1999. Influence of variety and growing location on the development of off-flavor in precooked vacuum-packed potatoes. J. Agr. Food Chem. 47:1145-1149.

Jiang, J., X. He, and D.E. Cane. 2006. Geosmin biosynthesis: Streptomyces coelicolor germacradienol/germacrene D synthase converts farnesyl diphosphate to geosmin. J. Amer. Chem. Soc. 128:8128-8129.

Korth, K.L., S.J. Doege, S.-H. Park, F.L. Goggin, Q. Wang, S.K. Gomez, G. Liu, L. Jia, and P.A. Nakata. 2006. Medicago truncatula mutants demonstrate the role of plant calcium oxalate crystals as an effective defense against chewing insects. Plant Physiol. 141:188-195.

Kelling, K.A., S.M. Combs, and J.B. Peters. 2002. Sampling for plant analysis. Dept. Soil Sci. Ext. Publ. Univ. Wisconsin-Madison.

Laboski, C.A.M. and J.B. Peters. 2012. Nutrient application guidelines for field, vegetable, and fruit crops in Wisconsin. Univ. Wisconsin. Ext. A2809. Lindsay, W.L. and W.A. Norvell. 1978. Development of a DTPA soil test for zinc, iron, manganese, and copper. Soil Sci. Soc. Amer. J. 42:421-428. Lu, G., C.G. Edwards, J.K. Fellman, D.S. Mattinson, and J. Navazio. 2003a. Biosynthetic origin of geosmin in red beets (Beta vulgaris L.). J. Agr. Food Chem. 51:1026-1029.

Lu, G., C.G. Edwards, J.K. Fellman, D.S. Mattinson, and J. Navazio. 2003b. Quantitative determination of geosmin in red beets (Beta vulgaris L.) using headspace solid-phase micro- extraction. J. Agr. Food Chem. 51:1021-1025.

Maher, L. 2017. Bidirectional recurrent selection and endogenous production of geosmin in table beet. PhD Diss. 1026389098, Univ. Wisconsin, Madison.
Maher, L. and I.L. Goldman. 2017. Bidirectional recurrent half-sib family selection for geosmin concentration in table beet. Crop Sci. 57:1-11.

Maher, L. and I.L. Goldman. 2018. Endogenous production of geosmin in table beet. HortScience 53:67-72.

McGrath, J.M. and L. Panella. 2018. Sugar beet breeding. Plant Breed. Rev. 42:167-218.

Marshall, A. and A.R. Hochstetler. 1968. The synthesis of $(+/-)$-geosmin and the other 1,10-dimethyl-9-decalol isomers. J. Org. Chem. 2501:2593-2595.

Mikołajczyk-Bator, K., A. Błaszczyk, M. Czyżniejewski, and P. Kachlicki. 2016. Characterisation and identification of triterpene saponins in the roots of red beets (Beta vulgaris L.) using two HPLCMS systems. Food Chem. 192:979-990.

Peters, J.B. and C.A.M. Laboski. 2013. Sampling soils for testing. Univ. Wisconsin. Ext. A2100.

Salinas, M.L., T. Ogura, and L. Soffchi. 2001. Irritant contact dermatitis caused by needle-like calcium oxalate crystals, raphides, in Agave tequilana among workers in tequila distilleries and agave plantations. Contact Dermat. 44:94-96.

Schlumpberger, B.O., A. Jux, M. Kunert, W. Boland, and D. Wittmann. 2004. Musty-earthy scent in cactus flowers: Characteristics of floral scent production in dehydrogeosmin-producing cacti. Int. J. Plant Sci. 165:1007-1015.

Schneider, K., R. Schafer-Pregl, D.C. Borchardt, and F. Salamini. 2002. Mapping QTLs for sucrose content, yield and quality in a sugar beet population fingerprinted by EST-related markers. Theor. Appl. Genet. 104:1107-1113.

Schrader, K.K. and W.T. Blevins. 2001. Effects of carbon source, phosphorus concentration, and several micronutrients on biomass and geosmin production by Streptomyces halstedii. J. Ind. Microbiol. Biotechnol. 26:241-247.

Shaul, O. 2002. Magnesium transport and function in plants: The tip of the iceberg. Biometals 15:309-323.

Singh, B., T.J. Oh, and J.K. Sohng. 2009. Exploration of geosmin synthase from Streptomyces peucetius ATCC 27952 by deletion of doxorubicin biosynthetic gene cluster. J. Ind. Microbiol. Biotechnol. 36:1257-1265.

Spiteller, D., A. Jux, J. Piel, and W. Boland. 2002. Feeding of $\left[5,5-^{2}\right.$ $\left.\mathrm{H}_{2}\right]$-1-desoxy-D-xylulose and $\left[4,4,6,6,6-{ }^{2} \mathrm{H}_{5}\right]$-mevalolactone to a geosmin-producing Streptomyces sp. and Fossombronia pusilla. Phytochemistry 61:827-834.

Trebbi, D. and J.M. McGrath. 2007. Genetics of water content in sugar beet roots. Proc. Amer. Soc. Sugar Beet Technologists Biennial Mtg. 44:135.

Tyler, L.D., T.E. Acree, and N.L. Smith. 1979. Sensory evaluation of geosmin in juice made from cooked beets. J. Food Sci. 44:79-81.

Tyler, L.D., T.E. Acree, R.F. Becker, R.R. Nelson, and R.M. Butts. 1978. Effect of maturity, cultivar, field history, and the operations of peeling and coring on the geosmin content of Beta vulgaris. J. Agr. Food Chem. 26:1466-1469.

U.S. Department of Agriculture. 2017. Quick stats. 9 Apr. 2019. $<$ https://www.nass.usda.gov/Quick_Stats/>.

Warncke, D. and J.R. Brown. 1982. Potassium and other basic cations, p. 31-33. In: J.R. Brown (ed.). Recommended chemical soil test procedures for the North Central region (rev.). Missouri Agr. Exp. Sta. SB1001.

Watson, M.E. 1998. Boron, p. 45-48. In: J.R. Brown (ed.). Recommended chemical soil test procedures for the North Central region (rev.). Missouri Agr. Exp. Sta., SB1001.

Wolyn, D.J. and W.H. Gabelman. 1990. Selection for betalain pigment concentrations and total dissolved solids in red table beets. J. Amer. Soc. Hort. Sci. 115:165-169.

Würschum, T., H.P. Maurer, T. Kraft, G. Janssen, C. Nilsson, and J.C. Reif. 2011. Genome-wide association mapping of agronomic traits in sugar beet. Theor. Appl. Genet. 123:1121-1131.

Zengin, M., F. Gökmen, M.A. Yazici, and S. Gezgin. 2009. Effects of potassium, magnesium, and sulphur containing fertilizers on yield and quality of sugar beets (Beta vulgaris L.). Turk. J. Agr. For. $33: 495-502$. 

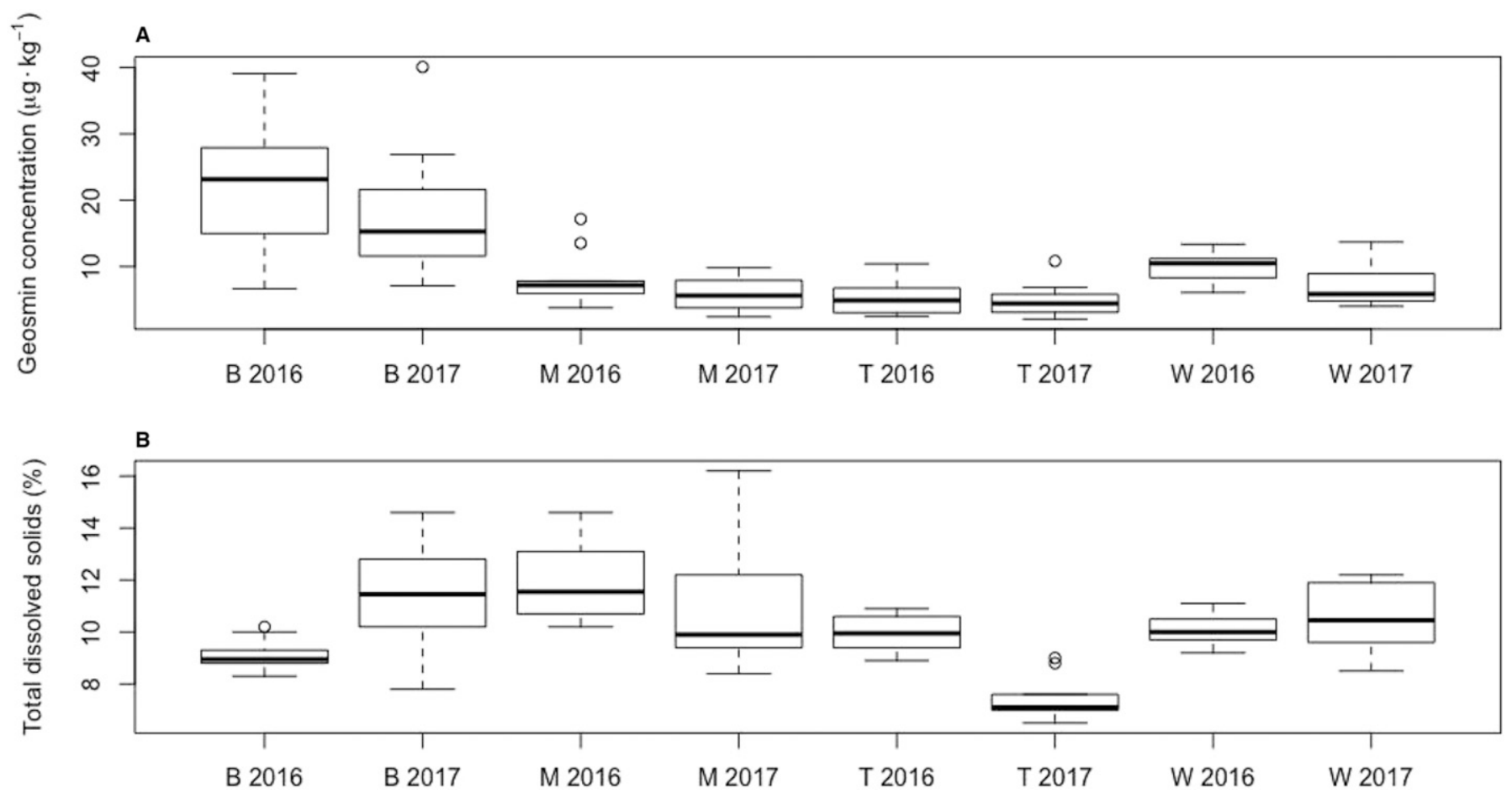

Supplemental Fig. 1. Box and whisker plots showing genotype median (A) geosmin concentration and (B) total dissolved solids of 10 individual roots per year of table beet genotypes Bull's Blood (B), Merlin (M), Touchstone Gold (T), and W357B (W), averaged over two Wisconsin field sites (Hancock, Madison). 

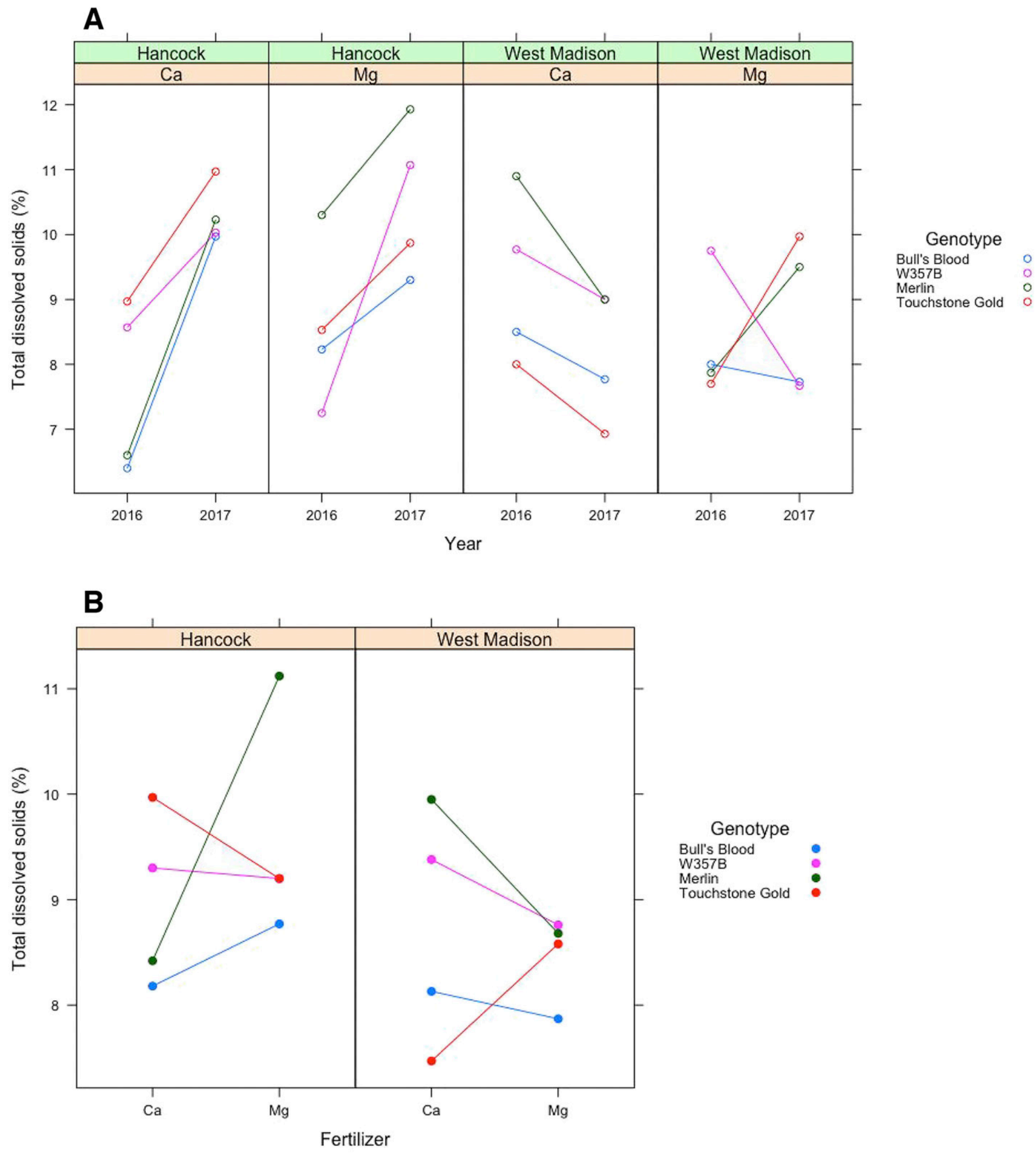

Supplemental Fig. 2. Interaction plots showing (A) significant genotype-fertilizer-year-site $(P<0.05)$ and $(\mathbf{B})$ genotype-fertilizer-site $(P<0.01)$ interactions for total dissolved solids in table beet genotypes Bull's Blood, W357B, Merlin, and Touchstone Gold grown at two Wisconsin field sites (Hancock, Madison), in 2016 and 2017, with $\mathrm{Ca}$ and $\mathrm{Mg}$ fertilizer treatments. Error bars are excluded for clarity. No pairwise comparisons are significant at $P \leq 0.05$ after Tukey-Kramer correction. 
Supplemental Table 1. Genotype mean geosmin concentration and total dissolved solids of 10 individual roots per year of table beet genotypes Bull's Blood, W357B, Merlin, and Touchstone Gold, averaged over two Wisconsin field sites (Hancock, Madison).

\begin{tabular}{|c|c|c|c|c|c|c|c|c|}
\hline & \multicolumn{2}{|c|}{ Bull's Blood } & \multicolumn{2}{|c|}{ W357B } & \multicolumn{2}{|c|}{ Merlin } & \multicolumn{2}{|c|}{ Touchstone Gold } \\
\hline & 2016 & 2017 & 2016 & 2017 & 2016 & 2017 & 2016 & 2017 \\
\hline Geosmin $\left(\mu \mathrm{g} \cdot \mathrm{kg}^{-1}\right)$ & $21.78 \mathrm{a}^{\mathrm{z}}$ & $17.89 \mathrm{ab}$ & $9.85 \mathrm{bc}$ & $6.86 \mathrm{c}$ & $8.22 \mathrm{c}$ & $5.99 \mathrm{c}$ & $5.23 \mathrm{c}$ & $4.84 \mathrm{c}$ \\
\hline TDS (\%) & $9.12 \mathrm{bc}$ & $11.39 \mathrm{a}$ & $10.04 \mathrm{ab}$ & $10.62 \mathrm{ab}$ & $11.89 \mathrm{a}$ & $11.00 \mathrm{ab}$ & $9.96 \mathrm{ab}$ & $7.43 \mathrm{c}$ \\
\hline
\end{tabular}

${ }^{\mathrm{z}}$ Different letters within the row denote significant difference in genotype means at $P \leq 0.05$ after Tukey-Kramer correction.

Supplemental Table 2. Mean $\mathrm{Mg}^{2+}$ and $\mathrm{Ca}^{2+}$ concentration of 'Merlin' table beet leaf tissue grown at two Wisconsin field sites (Hancock, Madison) in 2017. Six plots per site were sampled midseason and at harvest, or 7 and 12 to 13 weeks after planting, respectively.

\begin{tabular}{llcc}
\hline & & Hancock & Madison \\
\hline Midseason & $\mathrm{Mg}^{2+}\left(\mathrm{mg} \cdot \mathrm{kg}^{-1}\right)$ & $1.10 \mathrm{a}^{\mathrm{z}}$ & $0.91 \mathrm{~b}$ \\
\multirow{3}{*}{ Harvest } & $\mathrm{Ca}^{2+}\left(\mathrm{mg} \cdot \mathrm{kg}^{-1}\right)$ & $1.10 \mathrm{a}$ & $1.00 \mathrm{a}$ \\
& $\mathrm{Mg}^{2+}\left(\mathrm{mg} \cdot \mathrm{kg}^{-1}\right)$ & $0.83 \mathrm{a}$ & $0.76 \mathrm{a}$ \\
& $\mathrm{Ca}^{2+}\left(\mathrm{mg} \cdot \mathrm{kg}^{-1}\right)$ & $0.71 \mathrm{a}$ & $0.58 \mathrm{~b}$ \\
\hline
\end{tabular}

${ }_{\mathrm{z}}$ Different letters within the row denote significant difference in genotype means at $P \leq 0.05$ after Tukey-Kramer correction.

Supplemental Table 3. Total water applied via rain and irrigation, and mean daily temperature from 1 June to 30 Aug. at two Wisconsin field sites (Hancock, Madison) in 2016 and 2017.

\begin{tabular}{lcccccc}
\hline & \multicolumn{4}{c}{ Madison } & \multicolumn{3}{c}{ Hancock } \\
\cline { 2 - 7 } & 2016 & 2017 & Change 2016-17 & 2016 & 2017 & Change 2016-17 \\
\hline Total rain + irrigation $(\mathrm{cm})$ & 47 & 52 & $10 \%$ & 64 & 71 & $10 \%$ \\
Mean temperature $\left({ }^{\circ} \mathrm{C}\right)$ & 21 & 20.4 & $-3 \%$ & 20.6 & 19.4 & $-6 \%$ \\
\hline
\end{tabular}

